\title{
INSECTICIDAL PROPERTIES OF Peumus boldus Molina POWDER USED ALONE AND MIXED WITH LIME AGAINST Sitophilus zeamais Motschulsky (COLEOPTERA: CURCULIONIDAE)
}

\author{
Gabriel Bustos-Figueroa1, Francisco Osses-Ruiz ${ }^{1}$, Gonzalo Silva-Aguayo ${ }^{1 *}$, Maritza Tapia-Vargas ${ }^{1}$, \\ Ruperto Hepp-Gallo ${ }^{1 \dagger}$, and J. Concepción Rodríguez-Maciel ${ }^{2}$
}

\section{ABSTRACT}

The insecticidal properties of boldus (Peumus boldus Molina) powder used alone and mixed with lime against adults of maize weevil (Sitophilus zeamais Motschulsky) were evaluated under laboratory conditions. Additionally, aeration effects (presence or absence) and temperature (room temperature vs. $3{ }^{\circ} \mathrm{C}$ ) on insecticidal properties were studied over time. A mortality rate of $100 \%$ was observed at $20 \mathrm{~g} \mathrm{~kg}^{-1}(\mathrm{w} / \mathrm{w})$ of $P$. boldus powder when used alone and mixed with lime in proportions of 50:50, 60:40, and 80:20. The 50\% lethal concentration $\left(\mathrm{LC}_{50}\right)$ for all treatments was $<5 \mathrm{~g} \mathrm{~kg}^{-1}$, while $\mathrm{LC}_{90}$ was $<11 \mathrm{~g} \mathrm{~kg}^{-1}$. Mixing corn grains with different insecticidal treatments did not affect maize germination. Temperature and aeration did not influence mortality of maize weevil adults. When the boldus powder was mixed with the infested maize $24 \mathrm{~h}$ before grinding, the toxicity to the parental adults and emergence of F1 adults with respect to the untreated control was 100 and $0 \%$, respectively. The results were not satisfactory when boldus powder was stored during 30,60, and $90 \mathrm{~d}$ and then mixed with the infested maize. Boldus foliage toxicity was high $24 \mathrm{~h}$ after grinding, but decreased significantly over time.

Key words: Boldus, maize weevil, stored corn.

\section{INTRODUCTION}

A main problem for farmers after cereal harvest is grain loss during storage. This problem is important for small producers in developing countries due to grain destruction by pests such as rodents, insects, fungi, and bacteria (Larrain, 1994). In Chile, about 60 insect species attack stored food. The main pests associated with stored grains are Sitophilus zeamais Molina, Sitophilus oryzae Linnaeus, and Sitotroga cerealella Olivier (Larraín, 1994). Pest control of stored grains is based mainly on the use of conventional insecticides and synthetic fumigants (Porca et al., 2003). However, insecticide resistance, environmental contamination, and risk to human health are associated with the use of these toxics (Miranda et al., 1994). Thus, there is a need for other less expensive and friendlier alternatives.

${ }^{1}$ Universidad de Concepción, Facultad de Agronomía, Av. Vicente Méndez 595. Casilla 537, Chillán, Chile.

*Corresponding author (gosilva@udec.cl).

${ }^{2}$ Colegio de Postgraduados, Programa de Entomología y Acarología, km 36,5 Carretera México-Texcoco. PO Box 56230, Montecillo, Texcoco, Estado de México, México.

† Deceased September 2007.

Received: 21 January 2008.

Accepted: 18 April 2008.
The problems caused by overusing synthetic insecticides have forced farmers and researchers to look for less dangerous alternatives (Henao, 1999; Mareggiani, 2001) such as those used for many years in developing countries (Paez et al., 1990). Examples are the use of mineral powders and plant-derived substances with insecticidal properties (Miranda et al., 1994; Tierto, 1994; Subramanyam and Hagstrum, 2000). These compounds kill on contact and many have shown antifeeding, repellent, and even attractant properties (Mbah and Okoronkwo, 2008; Parugrug and Roxas, 2008).

Boldus (Peumus boldus Molina) is a tree or shrub native to Chile with medicinal properties (Vogel et al., 1999) which has shown toxic properties against $S$. zeamais in stored maize (Zea mays L.) (Silva et al., 2003a; 2005), and might be used as a low risk alternative for pest control in subsistence agriculture (Silva et al., 2003b). However, the use of boldus alone poses a logistic problem due to the difficulties associated in obtaining the necessary quantity of this plant. Other options include the use of mineral powders such as lime, calcium carbonate, diatomeus earth, and ash (Subramanyam and Roesli, 2000; Rahman et al., 2003), or using boldus mixed with mineral powders. Thus, the aim of this study conducted under laboratory 
conditions was to evaluate the insecticidal properties of $P$. boldus powder used alone and mixed with lime against $S$. zeamais, and determine the effect of aeration and temperature on the length of the toxic activity.

\section{MATERIALS AND METHODS}

\section{Plant material}

P. boldus foliage was collected from the Andean foothills, $36^{\circ} 52^{\prime} \mathrm{S}, 71^{\circ} 22^{\prime} \mathrm{W}$ and 1600 m.a.s.l., Bío-Bío Region, Chile. Once collected, leaves were dried during $48 \mathrm{~h}$ in a stove (Memmert Gmbh, UNB 500, Schwabach, Germany) at $40{ }^{\circ} \mathrm{C}$. After that, the foliage was ground in an electric coffee grinder (Moulinex ultra 505) to obtain a fine particulate powder, and sifted to a very fine powder with a 20 mesh $(0.841 \mathrm{~mm})$ sieve.

Maize cv. Laredo seeds were used in this study. Before use, grains were kept in a freezer at $-4{ }^{\circ} \mathrm{C}$ for $48 \mathrm{~h}$ in order to eliminate any external insect contamination that could affect the results.

\section{Mineral powder}

Lime was used as mineral powder because of its known insecticidal properties (Silva et al., 2004) and the wide availability of this compound in the market.

\section{Insects}

S. zeamais individuals were reared under controlled conditions in a bioclimatic chamber (Memmert Gmbh, INE 800 , Schwabach, Germany), $\left(25 \pm 2{ }^{\circ} \mathrm{C}\right.$ and 16:8 L:D photoperiod) using maize $\mathrm{cv}$. Laredo grains as food.

\section{Insecticidal effect}

The methodology proposed by Lagunes and Rodríguez (1989) was used to evaluate the insecticidal effect of the powders against $S$. zeamais adults. One hundred grams of maize were placed into $250 \mathrm{~mL}$ jars. Then, the respective treatment was added. The grain and toxic powder were manually mixed during $1 \mathrm{~min}$ to ensure that the grain was uniformly covered. The jar was then infested with 20 insect couples not older than $10 \mathrm{~d}$. Sex was determined using the criteria proposed by Halstead (1963) who determined that the rostrum of the female is longer, thinner, and less ornamented than the male's. Once the jars were infested, they were transferred to the bioclimatic chamber $\left(25 \pm 2{ }^{\circ} \mathrm{C}\right.$ and 16:8 L:D photoperiod).

The evaluated treatments were $P$. boldus powder used alone (100:0), lime used alone (0:100), and a mixture of both in proportions of 20:80, 40:60, 50:50; 60:40, and $80: 20(\mathrm{w} / \mathrm{w})$. In all cases, the treatments were evaluated at the 1,10 , and $20 \mathrm{~g} \mathrm{~kg}^{-1}(\mathrm{w} / \mathrm{w})$ concentrations.

After $15 \mathrm{~d}$ of insect infestation, adults were removed from each jar and the mortality percentage was determined.
The highest mortality in the untreated control was $10 \%$ whereas mortality in the toxic treatments was corrected with Abbott's formula (Abbott, 1925).

\section{Estimation of lethal concentrations $50 \%\left(\mathrm{LC}_{50}\right)$ and $\mathbf{9 0 \%}\left(\mathrm{LC}_{90}\right)$}

Serial concentrations were evaluated to determine the range in which 0 and $100 \%$ mortality was observed. Then, from five to seven intermediate concentrations were added. A total of five replications were carried out on different days and each one included an untreated control.

\section{Germination test}

Maize grain germination was evaluated only in those treatments that caused at least $80 \%$ mortality. Ten seeds were randomly selected from each of the replications and germinated in Petri dishes on wet paper towel at $25{ }^{\circ} \mathrm{C}$. Seed germination was determined one week later.

\section{Effect of the environmental factors on the insecticidal properties of $P$. boldus powder}

To evaluate the environmental factors on the toxicity of boldus, two types of containers ( $500 \mathrm{~mL}$ capacity) were used: perforated (to evaluate aeration effect ) and closed (to evaluate lack of aeration effect). Half of each type of container was kept at room temperature and half at $3{ }^{\circ} \mathrm{C}$ in order to evaluate temperature effect. Boldus foliage was ground and stored during $24 \mathrm{~h}, 30,60$, and $90 \mathrm{~d}$. Then, $100 \mathrm{~g}$ of corn grain was added to each container, mixed with boldus powder $\left(10 \mathrm{~g} \mathrm{~kg}^{-1}\right)$, and infested as explained above. Adult mortality was determined $15 \mathrm{~d}$ after insect infestation and the emergence of $\mathrm{F} 1$ adults was evaluated after $55 \mathrm{~d}$.

\section{Experimental design}

The toxic activity of boldus and lime used separately or as a mixture in different proportions was evaluated, as well as the germination test in a completely random design. Toxicity and germination tests consisted of 21 and 12 treatments, respectively. In both cases, five replications on different days were carried out. Each replication included an untreated control. The aeration and temperature effects on the residual toxicity of treatments were evaluated in a $2 \times 2$ factorial design with four treatments and five replications.

\section{Statistical analysis}

Before analysis, percentage mortality was transformed to the arcsine $\sqrt{x / 100}$ and then subjected to an analysis of variance (ANOVA, $\alpha=0.05$ ) with the SAS program (SAS Institute, 1998). Tukey's multiple comparison test $(\alpha=$ 0.05 ) was used to determine treatment differences. 
To determine the lethal concentrations that kill $50 \%\left(\mathrm{LC}_{50}\right)$ and $90 \%\left(\mathrm{LC}_{90}\right)$, data were subjected to the Probit analysis (Finney, 1971) using the Raymond Probit Analysis Program ${ }^{\circledR}$ software (Raymond, 1985).

\section{RESULTS AND DISCUSSION}

\section{Mortality}

As concentration increased, mortality also increased. With a $1 \mathrm{~g} \mathrm{~kg}^{-1}$ concentration, mortality tended to be higher as the proportion of lime in the mixture increased; the opposite was observed with 10 and $20 \mathrm{~g} \mathrm{~kg}^{-1}$ (Table 1). Mortality ranged from 8.2 to $100 \%$ (Table 1) in all treatments. The least effective treatments were those using a $1 \mathrm{~g} \mathrm{~kg}^{-1}$ concentration where mortality was $<$ $50 \%$. With 10 and $20 \mathrm{~g} \mathrm{~kg}^{-1}$, mortality was $>50 \%$, and with proportions of $60: 40,80: 20$, and 100:0, mortality of adult insects was $100 \%$ (Table 1). The high mortality percentages produced by $P$. boldus powder used alone agree with the results obtained by Paez et al. (1990), Silva et al. $(2001 ; 2005)$ with $100 \%, 99.1 \%$, and $99.3 \%$ insect mortality, respectively. The value obtained with lime was similar to that reported by Silva et al. (2004)

Table 1. Adult mortality of Sitophilus zeamais in maize treated with different proportions of Peumus boldus and lime.

\begin{tabular}{|c|c|c|}
\hline Concentration & $\begin{array}{c}\text { Treatment } \\
\text { Boldus:lime } \\
\text { (weight/weight) }\end{array}$ & Mortality $^{1}$ \\
\hline $\mathrm{g} \mathrm{kg}^{-1}$ & & $\%$ \\
\hline \multirow[t]{7}{*}{1} & $0: 100$ & $47.0 \mathrm{fg}$ \\
\hline & $20: 80$ & 43.8fgh \\
\hline & $40: 60$ & $20.6 \mathrm{ij}$ \\
\hline & $50: 50$ & 26.0ghi \\
\hline & $60: 40$ & 22.4hij \\
\hline & $80: 20$ & $15.2 \mathrm{ij}$ \\
\hline & 100:0 & $8.2 \mathrm{j}$ \\
\hline \multirow[t]{7}{*}{10} & $0: 100$ & 66.0efi \\
\hline & $20: 80$ & 67.0efi \\
\hline & $40: 60$ & $93.8 b c$ \\
\hline & $50: 50$ & $97.7 \mathrm{abc}$ \\
\hline & $60: 40$ & $100.0 \mathrm{a}$ \\
\hline & $80: 20$ & $100.0 \mathrm{a}$ \\
\hline & 100:0 & $100.0 \mathrm{a}$ \\
\hline \multirow[t]{7}{*}{20} & $0: 100$ & 75.7ed \\
\hline & $20: 80$ & $90.4 \mathrm{dc}$ \\
\hline & $40: 60$ & $99.4 \mathrm{ab}$ \\
\hline & $50: 50$ & $100.0 \mathrm{a}$ \\
\hline & $60: 40$ & $100.0 \mathrm{a}$ \\
\hline & $80: 20$ & $100.0 \mathrm{a}$ \\
\hline & 100:0 & $100.0 \mathrm{a}$ \\
\hline
\end{tabular}

Treatments with the same letter in the columns are not statistically different according to Tukey test $(\alpha=0.05)$.

'Mortality corrected with Abbott's formula. with a $10 \mathrm{~g} \mathrm{~kg}^{-1}$ concentration and $100 \%$ mortality. The insecticidal effect of boldus is probably due to the alkaloids it contains. Alkaloids are known for their toxic properties, such as in nicotine (Lagunes and Villanueva, 1994), but boldine, the main boldus alkaloid, is present in very small concentrations (0.2 to $0.5 \%$ ) (Vogel et al., 1999). However, Perez et al. (2007) did not find any correlation between the alkaloid concentration and mortality of $S$. zeamais.

\section{$\mathrm{LC}_{50}$ and $\mathrm{LC}_{90}$ values}

Values for $\mathrm{LC}_{50}$ ranged from 0.41 to $4.27 \mathrm{~g} \mathrm{~kg}^{-1}$ and from 1.18 to $10.43 \mathrm{~g} \mathrm{~kg}^{-1}$ for $\mathrm{LC}_{90}$ (Table 2). The most toxic treatments at the $\mathrm{LC}_{90}$ level were the $60: 40$ and 80:20 proportions which required only 1.18 and 1.23 $\mathrm{g} \mathrm{kg}^{-1}$ powder, respectively. These results confirm a positive synergistic effect of the mixture of $P$. boldus and lime. Slope values (Table 2) of the Dose-Probit Line (Ldp) (Figure 1) show that the greatest homogeneity in population response (slope 4.44) was achieved with the 50:50 treatment. Therefore, to achieve higher mortality, concentration must be increased less than in the other treatments. Ldp is a straight line indicating a unimodal response of S. zeamais to the treatments.

\section{Germination test}

No treatment was statistically different from the untreated control and values ranged from 86.7 to $100 \%$ (Table 3). Additionally, $100 \%$ germination was obtained with 40:60 and $10 \mathrm{~g} \mathrm{~kg}^{-1}(\mathrm{w} / \mathrm{w}), 50: 50$ and 60:40 with 20 $\mathrm{g} \mathrm{kg}^{-1}$, and 80:20 with 10 and $20 \mathrm{~g} \mathrm{~kg}^{-1}$. P. boldus powder (100:0) at concentrations of 10 and $20 \mathrm{~g} \mathrm{~kg}^{-1}$ (w/w) achieved $96.7 \%$ and $93.3 \%$ germination, respectively. Consequently, the analysis of this parameter indicates that $P$. boldus powder used alone or mixed with lime does not significantly affect the percentage of seed germination.

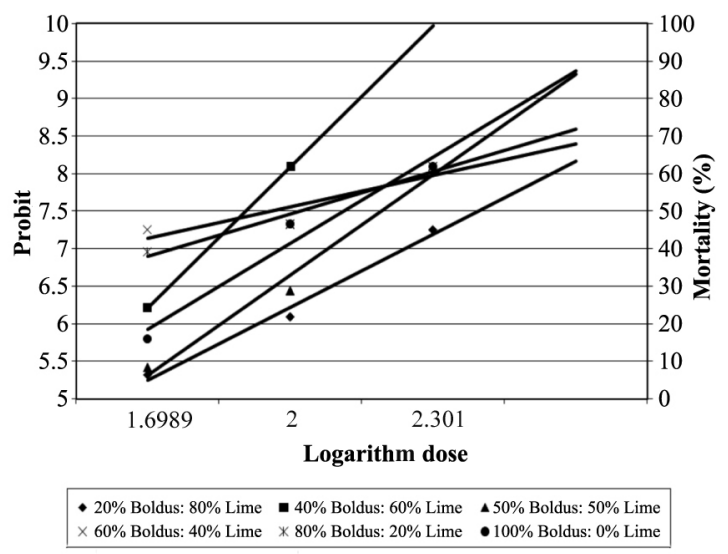

Figure 1. Dose-Probit Line (Ldp) for evaluated treatments to control Sitophilus zeamais in stored maize. 
Table 2. Lethal concentrations of the most effective Peumus boldus and lime treatments on Sitophilus zeamais adults.

\begin{tabular}{|c|c|c|c|c|}
\hline $\begin{array}{l}\text { Boldus: Lime } \\
\text { (Proportion weight:weight) }\end{array}$ & $\mathbf{L C}_{50}$ & $\mathbf{L C}_{90}$ & $\begin{array}{l}\text { Equation } \\
\mathbf{Y}=\mathbf{a}+\mathbf{b x}\end{array}$ & $\begin{array}{c}\text { Coefficient of } \\
\text { determination }\left(r^{2}\right)\end{array}$ \\
\hline & 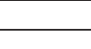 & & & \\
\hline $20: 80$ & 4.20 & 10.43 & $Y=2.99+3.22 X$ & 0.99 \\
\hline $40: 60$ & 3.26 & 7.39 & $Y=3.16+3.58 X$ & 0.84 \\
\hline $50: 50$ & 4.27 & 8.25 & $Y=2.20+4.44 X$ & 0.98 \\
\hline 60:40 & 0.14 & 1.18 & $Y=6.17+1.38 X$ & 0.81 \\
\hline $80: 20$ & 0.49 & 1.23 & $Y=5.58+1.87 X$ & 0.96 \\
\hline 100:0 & 2.86 & 6.30 & $\mathrm{Y}=3.26+3.81 \mathrm{X}$ & 0.96 \\
\hline
\end{tabular}

$\mathrm{LC}_{50}$ : Concentration that kills $50 \%$ of the treated individuals.

$\mathrm{LC}_{90}$ : Concentration that kills $90 \%$ of the treated individuals.

Table 3. Germination in maize seeds treated with different Peumus boldus and lime proportions.

\begin{tabular}{lcc}
\hline $\begin{array}{l}\text { Boldus: Lime } \\
\text { (Proportion weight:weight) }\end{array}$ & Concentration & Germination \\
\hline & $\mathrm{g} \mathrm{kg}^{-1}$ & $\%$ \\
$20: 80$ & 20 & $93.3 \mathrm{a}$ \\
$40: 60$ & 10 & $100.0 \mathrm{a}$ \\
$40: 60$ & 20 & $96.7 \mathrm{a}$ \\
$50: 50$ & 10 & $93.3 \mathrm{a}$ \\
$50: 50$ & 20 & $100.0 \mathrm{a}$ \\
$60: 40$ & 10 & $96.7 \mathrm{a}$ \\
$60: 40$ & 20 & $100.0 \mathrm{a}$ \\
$80: 20$ & 10 & $100.0 \mathrm{a}$ \\
$80: 20$ & 20 & $100.0 \mathrm{a}$ \\
$100: 0$ & 10 & $96.7 \mathrm{a}$ \\
$100: 0$ & 20 & $93.3 \mathrm{a}$ \\
Testigo & - & $86.7 \mathrm{a}$ \\
\hline
\end{tabular}

Treatments with the same letter in the columns are not statistically different according to Tukey test $(\alpha=0.05)$.

Effect of environmental factors on insecticidal properties of $P$. boldus powder

Mortality. There were no statistical differences with respect to aeration (presence or absence) or temperature (room temperature or $3{ }^{\circ} \mathrm{C}$ ). However, the time that the boldus powder remained in storage ( $24 \mathrm{~h}, 30 \mathrm{~d}, 60 \mathrm{~d}$, and $90 \mathrm{~d}$ ) greatly affected treatment toxicity. Mortality was $>97 \%$ in all treatments after $24 \mathrm{~h}$, whereas at 30,60, and $90 \mathrm{~d}$, mortality was $<53 \%$ (Table 4 ) which is not considered promising according to criteria set by Lagunes and Rodríguez (1989). Our results agreed with those obtained by Paez et al. (1990) and Silva et al. (2003b; 2005) who claimed a mortality of $100 \%, 99.1 \%$, and $99.3 \%$, respectively after $24 \mathrm{~h}$. Mortality with boldus powder at 30,60 , and $90 \mathrm{~d}$ storage was similar to that found by Silva et al. (2005), who obtained percentages close to $2 \%$ for the same periods.

\section{Emergence of F1 adults}

There were no aeration (presence or absence) or temperature (room temperature or $3{ }^{\circ} \mathrm{C}$ ) effects on the emergence of F1 adults with respect to the untreated control (Tukey, $\alpha=0.05$ ) (Table 5). Mortality was greatly influenced by boldus powder storage time $(24 \mathrm{~h}, 30$, 60 , and $90 \mathrm{~d}$ ) before insect infestation (Table 5). There was no emergence of F1 adults after $24 \mathrm{~h}$. In the rest of the treatments, the emergence of F1 adults compared to the untreated control did not reach satisfactory results according to criteria set by Lagunes and Rodríguez (1989). The result obtained after $24 \mathrm{~h}$ was probably due to the $100 \%$ mortality achieved in parent adults and to the fact that the parent females died before laying eggs.

\section{CONCLUSIONS}

Mortality of adults was positively correlated with treatment concentration. At $1 \mathrm{~g} \mathrm{~kg}^{-1}(\mathrm{w} / \mathrm{w})$, toxicity increased as the proportions of boldus in the mixture increased, but the opposite was observed at 10 and 20 $\mathrm{g} \mathrm{kg}^{-1}(\mathrm{w} / \mathrm{w})$. In all cases, the evaluated treatments did not affect maize germination. There were no aeration (presence or absence) or temperature (room temperature 
Table 4. Mortality of Sitophilus zeamais adults treated with Peumus boldus powder with $1 \mathrm{~g} \mathrm{~kg}^{-1}$ concentration and exposed to different environmental conditions.

\begin{tabular}{|c|c|c|c|c|}
\hline \multirow[b]{2}{*}{ Treatment } & \multicolumn{4}{|c|}{ Mortality (\%) } \\
\hline & $24 \mathrm{~h}$ & $30 \mathrm{~d}$ & $60 \mathrm{~d}$ & $90 \mathrm{~d}$ \\
\hline \multicolumn{5}{|l|}{ Aeration } \\
\hline Room temperature & $97 \mathrm{a}$ & $13 \mathrm{a}$ & $13 \mathrm{a}$ & $32 \mathrm{a}$ \\
\hline $3^{\circ} \mathrm{C}$ & $98 \mathrm{a}$ & $25 \mathrm{a}$ & $10 \mathrm{a}$ & $48 \mathrm{a}$ \\
\hline \multicolumn{5}{|l|}{ No aeration } \\
\hline Room temperature & $100 \mathrm{a}$ & $20 \mathrm{a}$ & $17 \mathrm{a}$ & $33 a$ \\
\hline $3^{\circ} \mathrm{C}$ & $100 \mathrm{a}$ & $37 \mathrm{a}$ & $18 \mathrm{a}$ & $53 a$ \\
\hline
\end{tabular}

Values with the same letter and inside the same column are not statistically different according to Tukey test $(\alpha=0.05)$.

Table 5. Emergence of F1 Sitophilus zeamais adults treated with Peumus boldus powder with $1 \mathrm{~g} \mathrm{~kg}^{-1}$ concentration and subjected to different environmental conditions.

\begin{tabular}{lcccc}
\hline & \multicolumn{3}{c}{ Emergence of F1 adults with respect to the untreated control (\%) } \\
\cline { 2 - 4 } Treatment & $\mathbf{2 4} \mathbf{~ h}$ & $\mathbf{3 0 ~ d}$ & $\mathbf{6 0 ~ d}$ & $\mathbf{9 0 ~ d}$ \\
\hline Aeration & & & \\
$\quad$ Room temperature & $0 \mathrm{a}$ & $83 \mathrm{a}$ & $90 \mathrm{a}$ & $61 \mathrm{ab}$ \\
$3{ }^{\circ} \mathrm{C}$ & $0 \mathrm{a}$ & $53 \mathrm{a}$ & $94 \mathrm{a}$ & $47 \mathrm{ab}$ \\
No aeration & & & \\
Room temperature & $0 \mathrm{a}$ & $66 \mathrm{a}$ & $85 \mathrm{a}$ & $99 \mathrm{ab}$ \\
$3{ }^{\circ} \mathrm{C}$ & $0 \mathrm{a}$ & $48 \mathrm{a}$ & $88 \mathrm{a}$ & $45 \mathrm{ab}$ \\
\hline
\end{tabular}

Values with the same letter and inside the same column are not statistically different according to Tukey test $(\alpha=0.05)$.

or $3{ }^{\circ} \mathrm{C}$ ) effects on treatment toxicity. Mortality and emergence of F1 adults compared to the untreated control was highly influenced by the time the boldus powder was stored before insect infestation. Once the foliage of boldus is ground, its toxic properties remain satisfactory during a short time (24 h).

\section{RESUMEN}

Propiedades insecticidas del polvo de Peumus boldus Molina: solo y en mezcla con cal contra Sitophilus zeamais Motschulsky (Coleoptera: Curculionidae). Se evaluaron las propiedades insecticidas del polvo de boldo (Peumus boldus Molina) solo y en mezcla con cal, bajo condiciones de laboratorio. Adicionalmente, se evaluó el efecto de la aeración (presencia vs. ausencia) y de la temperatura (temperatura ambiente vs. $3{ }^{\circ} \mathrm{C}$ ) sobre la mortalidad y emergencia de adultos de la F1. La concentración de $20 \mathrm{~g} \mathrm{~kg}^{-1}$ (p/p) del polvo de boldo ya sea solo o en combinación con cal en las proporciones de 50:50, 60:40 y 80:20 mostraron 100\% de mortalidad. La concentración letal $50 \%\left(\mathrm{CL}_{50}\right)$, en todos los tratamientos fue menor a $5 \mathrm{~g} \mathrm{~kg}^{-1}(\mathrm{p} / \mathrm{p})$ mientras que la $\mathrm{CL}_{90}$ no superó $11 \mathrm{~g} \mathrm{~kg}^{-1}(\mathrm{p} / \mathrm{p})$. La mezcla del polvo con los granos de maíz tanto solo como en mezcla con cal no afectó la germinación. La temperatura y la aeración no afectaron la mortalidad de los adultos parentales ni la emergencia de adultos de la F1. Cuando se mezcló el maíz con el polvo de boldo molido $24 \mathrm{~h}$ antes de la infestación con adultos, la mortalidad de los adultos parentales y la emergencia de adultos de la F1 fue de $100 \mathrm{y}$ de $0 \%$, respectivamente. Los resultados no fueron satisfactorios cuando el polvo de boldo almacenado durante 30, 60 y 90 d fue mezclado con el maíz infestado. La toxicidad del follaje de boldo es alta $24 \mathrm{~h}$ después de pulverizarse; si el tiempo es mayor, la toxicidad declina significativamente.

Palabras clave: boldo, gorgojo del maíz, maíz almacenado.

\section{LITERATURE CITED}

Abbott, W.A. 1925. A method for computing the effectiveness of an insecticide. J. Econ. Entomol. 18:265-267.

Finney, D. 1971. Probit analysis. 333 p. Cambridge University Press, Cambridge, UK.

Halstead, D.G.H. 1963. External sex differences in storedproducts. Bull. Entomol. Res. 54:119-134. 
Henao, S. 1999. Efecto a largo plazo de los plaguicidas sintéticos. Manejo Integrado de Plagas 51:84-86.

Lagunas, A., y C. Rodríguez. 1989. Búsqueda de la tecnología apropiada para el combate de plagas del maíz almacenado en condiciones rústicas. $150 \mathrm{p}$. CONACYT/Colegio de Postgraduados, Montecillo, México.

Lagunas, A., y J. Villanueva. 1994. Toxicología y manejo de insecticidas. 264 p. Colegio de Postgraduados, Montecillo, México.

Larraín, P. 1994. Manejo integrado de plagas en granos almacenados. Investigación y Progreso Agropecuario La Platina 81:10-16.

Mareggiani, G. 2001. Manejo de insectos plaga mediante sustancias semioquímicas de origen vegetal. Manejo Integrado de Plagas 60:22-30.

Mbah, O.I., and O. Okoronkwo. 2008. An assessment of two plant product efficacy for the control of the maize weevil (Sitophilus zeamais Motschulsky) in stored maize. Afr. J. Agric. Res. 3:494-498.

Miranda, D., J. Ayala, y R. Domínguez. 1994. Extractos y polvos vegetales con propiedades insecticidas: una alternativa en el combate del gorgojo del maíz, Sitophilus zeamais Motschulsky (Coleoptera: Curculionidae), en granos almacenados. Rev. Chapingo 1:71-75.

Paez, A., A. Lagunas, J.L. Carrillo, y C. Rodríguez. 1990. Polvos vegetales y materiales inertes para el combate del gorgojo Sitophilus zeamais (Coleoptera: Curculionidae) en maíz almacenado. Agrociencia 1:35-46.

Parugrug, M., and A. Roxas. 2008. Insecticidal action of five plants against maize weevil, Sitophilus zeamais Motsch. (Coleoptera: Curculionidae). KMITL Sci. Tech. J. 8:24-38.

Pérez, F., G. Silva, M. Tapia, y R. Hepp. 2007. Variación anual de las propiedades insecticidas de Peumus boldus sobre Sitophilus zeamais. Pesq. Agropec. Bras. 42:633-639.

Porca, M., I. Ghizdavu, I. Oltean, and H. Bunescu. 2003. Control of the coleopteres in stored agricultural products by not-chemical methods. J. Cent. Eur. Agric. (online) 4:217-220.

Rahman, M.A., M.A. Taleb, and M.M. Biswas. 2003. Evaluation of botanical products as grain protectant against grain weevil, Sitophilus zeamais (L.) on wheat. Asian J. Plant Sci. 2:501-504.
Raymond, M. 1985. Présentation d'un programme d'analyse log-probit pour micro-ordinateur. Entomol. Med. Parasitol. 22:117-121.

SAS Institute. 1998. Language guide for personal computer release 6.03. 1028 p. SAS Institute, Cary, North Carolina, USA.

Silva, G., P. González, R. Hepp, y P. Casals. 2004. Control de Sitophilus zeamais Motschulsky con polvos inertes. Agrociencia 38:529-536.

Silva, G., A. Lagunes, y J. Rodríguez. 2003a. Control de Sitophilus zeamais (Coleoptera: Curculionidae) con polvos vegetales solos y en mezcla con carbonato de calcio en maíz almacenado. Cienc. Inv. Agr. 30:153160.

Silva, G., A. Lagunes, J.C. Rodríguez, y D. Rodríguez. 2001. Insecticidas vegetales; una vieja nueva opción en el combate de insectos. Revista Manejo Integrado de Plagas y Agroecologia 66:4-12.

Silva, G., O. Orrego, R. Hepp, y M. Tapia. 2005. Búsqueda de plantas con propiedades insecticidas para el control de Sitophilus zeamais en maíz almacenado. Pesq. Agropec. Bras. 40:11-17.

Silva, G., D. Pizarro, P. Casals, y M. Berti. 2003b. Evaluación de plantas medicinales en polvo para el control de Sitophilus zeamais Motschulsky en maíz almacenado. Rev. Bras. Agrocienc. 9:383-388.

Subramanyam, B., and D. Hagstrum. 2000. Botanicals. p. 303-320. In Subramanyam, B., and D.W. Hagstrum (eds.) Alternatives to pesticides in stored-product IMP. Kluwer Academic Publishers, Boston, Massachussets, USA.

Subramanyam, B., and R. Roesli. 2000. Inert dust. p. 321379. In Subramanyam, B., and D.W. Hagstrum (eds.) Alternatives to pesticides in stored-product IMP. Kluwer Academic Publishers, Boston, Massachussets, USA.

Tierto, B. 1994. The ability of powders and slurries from ten plant species to protect stored grain from attack by Prostephanus truncatus Horn (Coleoptera: Bostrichidae) and Sitophilus oryzae L. (Coleoptera: Curculionidae). J. Stored Product Res. 30:297-301.

Vogel, H., I. Razmilic, M. Muñoz, U. Doll, and J. San Martin. 1999. Studies of genetic variation of essential oil alkaloid content in Boldo (Peumus boldus). Planta Med. 65:90-91. 